\title{
Expression of Aß-Fc Fusion Protein in Transgenic Potato
}

\author{
Hyun-Soon Kim $^{1 \dagger}$, Jung Won Youm ${ }^{1 \dagger}$, Jeong-Hwan Lee ${ }^{2,3}$, Jae-Heung Jeon ${ }^{1}$, and Kisung Ko ${ }^{2,3^{*}}$ \\ ${ }^{1}$ Plant Systems Engineering Research Center, Korea Research Institute of Bioscience \& Biotechnology, Daejeon 305-806, Korea \\ ${ }^{2}$ Department of Medicine, College of Medicine, Chung-Ang University, Seoul 156-756, Korea \\ ${ }^{3}$ Medical Research Institute, Chung-Ang University, Seoul 156-756, Korea
}

\begin{abstract}
Transgenic potato was generated to express recombinant 5 repeated $\beta$-amyloid (A $\beta$ ) peptides, potential antigens to be applied as a preventive accine for Alzheimer's disease using Agrobacterium mediated transformation. The A $\beta$ peptides were fused to the human IgG Fc fragment enhancing protein and KDEL, which is the endoplasmic reticulum (ER) retention signal $(5 \mathrm{~A} \beta-\mathrm{FcK})$. The $5 \mathrm{~A} \beta-\mathrm{FcK}$, was expressed under the control of the duplicated $35 \mathrm{~S}$ promoter. PCR analysis confirmed the presence of the transgene in several transgenic potato lines. Southern blot analysis showed only a single gene copy number in transgenic line 22, whereas multiple gene copy numbers were shown for transgenic lines 31 and 44. Northern blot analysis showed that line 22 had stronger mRNA levels when compared to lines 31 and 44 . Immunoblot analysis confirmed that the $5 \mathrm{~A} \beta$-FcK protein was expressed in the transgenic potato plant. These results indicate that $5 \mathrm{~A} \beta$ fused to Fc can be expressed in potato plants.
\end{abstract}

Additional key words: $5 \mathrm{~A} \beta-\mathrm{FcK}$, Alzheimer's disease, fusion protein, transgenic potato, $\beta$-amyloid

\section{Introduction}

Alzheimer's disease (AD), the most common form of dementia in the elderly is believed to be caused by the formation of amyloid plaques in the brain, which are made up of small peptides (i.e., 39-43 amino acids) called $\beta$ -amyloids (Aßs) (Racchi et al., 2008; Weiner HL and Frenkel $D, 2006)$. Mice were immunized with synthetic $A \beta$ to produce anti- $\mathrm{A} \beta$ antibodies, thus, preventing the formation of amyloid plaques and protecting transgenic $\mathrm{AD}$ mice from AD (Morgan et al., 2000; Schenk et al., 1999). Although the results from the $A \beta$ vaccination experiment in the transgenic mice were promising, this approach to $\mathrm{AD}$ patients resulted in meningoencephalitis (Nicoll et al., 2003; Orgogozo et al., 2003). Thus, the vaccine production, immunization protocols, and vaccine structures have been newly modified and improved to reduce such adverse effects (Moretto et al., 2007). Biotechnology and genetic engineering techniques have been used to produce subunit vaccines that stimulate a strong immune response. To create the subunit vaccine, the genes encoding the appropriate subunits are isolated from the genome of the infectious agent and expressed in bacteria (Ma et al., 2013), yeast (Wang et al., 2013), insects (Kanai et al., 2013), and plant host cells (Chen and Lai, 2013), which then produce large quantities of the subunit molecules. Subunit vaccines are safe for use in immunocompromised patients because they do not cause disease (Emini et al., 1986). Plants are considered to be an alternative expression system for the production of recombinant protein and oral immunization with several advantages, including low-cost production, the lack of human pathogen contaminants, and easy post-translational modification (e.g., glycosylation, an important factor in the biological activity of glycoproteins) (Agarwal, 2008; Brodzik, 2006; Ko, 2003; Ma, 2003; Richter, 2000; Tacket, 1998). We previously reported that $A \beta$ is expressed in plants and biologically functions to induce immune responses in mice (Youm et al., 2005, 2008). Successful protective immunization requires optimized vaccine structures for proper administration protocols, efficient uptake, and presentation by an

\footnotetext{
*Corresponding author:ksko@cau.ac.kr

${ }^{\dagger}$ These authors contributed equally to this work.

※ Received 23 September 2013; Revised 23 November 2013; Accepted 5 February 2014. This works were supported by grant from the KRIBB Research Initiative Program and grant (Code\# PJ009419022014) from the Korean Rural Development Administration.

(C) 2014 Korean Society for Horticultural Science
} 
antigen-presenting cell (APC) (Kreutz et al., 2012). Thus, the biologic properties of the vaccine and its expression level have been optimized in plant production systems ( $\mathrm{Lu}$ et al., 2012). To achieve both the goals, vaccine sequences have been fused to extra sequences, such as cholera toxin B (CTB) (Langridge et al., 2010), GUS (Cueno et al., 2010), and flagellin (Cuadros et al., 2004), for use as adjuvants or for stabilization. Furthermore, the plant-made vaccine is often purified by its fusion to the multi-His tag for an injectable vaccination approach (Buyel et al., 2012). Fusion of the IgG Fc fragment to the vaccine is another approach that makes it easy to purify the recombinant vaccine expressed in plants (Lu et al., 2012). Fusion of the IgG Fc fragment to the vaccine may potentially have properties such as enhanced efficacy of the vaccination by efficiently targeting it to the APCs and increasing the half-life ( $\mathrm{Hu}, 2008$; Mosolits et al., 2004). Furthermore, the fusion of the IgG Fc fragment to the vaccine was shown to provide higher expression levels, better yields, and increased stability in plant expression systems (Lu et al., 2012). Indeed, the Fc domain helps to solubilize hydrophobic proteins and allows for easy detection and purification of the fusion proteins in mammalian cells (Lo et al., 1998). Stable accumulation of the recombinant protein in the endoplasmic reticulum (ER) was achieved by fusion with the KDEL ER-retention signal, which is quite advantageous in establishing high expression levels of recombinant proteins (Gradinaru, 2008; Urakami, 2008). The aim of this study was to investigate whether the $5 \mathrm{~A} \beta$ -FcK fusion can be expressed in the transgenic potato plant.

\section{Materials and Methods}

\section{Construction of Gene Expression Cassette}

Five times repeated $A \beta(5 A \beta)$ was fused with the $F c$ region of human immunoglobulin $\mathrm{G}_{1}\left(\operatorname{IgG}_{1}\right)$ (Fig. 1). The $5 \mathrm{~A} \beta$ was cloned under the control of the cauliflower mosaic virus 35S promoter (containing the upstream enhancer region) into the pMBP1 vector. The $5 A \beta$ expression gene cassette in the pMBP1 vector was cut by using the HindIII restriction enzyme and inserted into the p13Zf subcloning vector. The Fc region was amplified using the forward primer $5^{\prime}$-GCG GAT CCG TTG AGC CCA AAT CTT GTG ACA AA- $3^{\prime}$ and reverse primer $5^{\prime}$-GCT CTA GAT CAG AGT TCA TCT TTA CCC GGG GAC AGG GAG AG-3' containing BamHI and $X b a \mathrm{I}$ and fused to the $3^{\prime}$ end of the $5 A \beta$ gene in p13Zf. The $5 A \beta-F C K$ fusion-gene expression cassette was transferred to a plant expression vector pBINPLUS, yielding pBIN5AF for Agrobacterium-mediated transformation.

\section{Generation of Transgenic Plants}

Agrobacterium-mediated transformation was conducted for potato leaf explants by using the plant expression vector pBIN5AF. A tumefaciens carrying pBIN5AF was suspension cultured in LB broth supplemented with kanamycin at $27^{\circ} \mathrm{C}$ for $2 \mathrm{~d}$. The cultured Agrobacterium was centrifuged at $4,000 \mathrm{rpm}$ for $20 \mathrm{~min}$, and the pellet was resuspended in an MS (Murashihe \& Skoog, 1962) liquid medium with 100 $\mu \mathrm{M}$ acetosyringone at $27^{\circ} \mathrm{C}$ with gentle shaking for $4 \mathrm{~h}$. The potato leaves were sliced and incubated in Agrobacteriumcultured MS liquid medium with acetosyringone $\left(250 \mu \mathrm{g} \cdot \mathrm{mL}^{-1}\right)$ for $10 \mathrm{~min}$ while shaking. For effective transformation, the explants were placed in a co-culture medium containing $2.0 \mathrm{mg} \cdot \mathrm{L}^{-1}$ of 2 , 4-D. Two days later, the explants were transferred to the regeneration medium containing $2.0 \mathrm{mg} \cdot \mathrm{L}^{-1}$ zeatin, $0.01 \mathrm{mg} \cdot \mathrm{L}^{-1} \mathrm{NAA}, 0.1 \mathrm{mg} \cdot \mathrm{L}^{-1} \mathrm{GA}_{3}, 100 \mathrm{mg} \cdot \mathrm{L}^{-1}$ kanamycin, $1,000 \mathrm{mg} \cdot \mathrm{L}^{-1}$ carbenicillin. All plant hormones and antibiotics were filter-sterilized and added to the autoclaved medium. The explants were transferred to the fresh medium every 2 weeks intervals. The shoots generated from transformed leaf discs on selective medium were containing $50 \mathrm{mg} \cdot \mathrm{L}^{-1}$ kanamycin and $1,000 \mathrm{mg} \cdot \mathrm{L}^{-1}$ carbenicillin.

\section{Polymerase Chain Reaction (PCR) Amplification of Genomic DNA}

Genomic DNA was isolated from the fresh leaf tissue of transgenic and non-transgenic potato plants using a DNA extraction kit (iNtRON Biotechnology, Seoul, Korea) according to the manufacturer's recommendations. PCR amplification of genomic DNA was performed to confirm the presence of the recombinant genes using the following primer pairs: the forward primer, $5^{\prime}$-GCG GAT CCG TTG AGC CCA AAT CTT GTG ACA AA- $3^{\prime}$ and the reverse primer $5^{\prime}$-GCT CTA GAT CAG AGT TCA TCT TTA CCC GGG GAC AGG GAG AG-3' PCR was performed with 38 cycles at $94^{\circ} \mathrm{C}$ for $60 \mathrm{~s}, 55^{\circ} \mathrm{C}$ for $60 \mathrm{~s}$, and $72^{\circ} \mathrm{C}$ for $60 \mathrm{~s}$.

\section{Southern Blotting}

From the transgenic plants, $30 \mu \mathrm{g}$ of genomic DNA was digested using the Sall restriction enzyme (New England BioLabs Inc., Ipswich, MA). Isolated DNA was subjected to electrophoresis in a $0.8 \%$ agarose gel and $1 \times$ TBE buffer. Total genomic DNA was extracted according to the cetyl trimethyl ammonium bromide (CTAB) protocol described by Doyle and Doyle (1990). The genomic DNA was digested using SalI to determine the copy numbers of the DNA inserted into the independent potato transgenic lines 22 , 31 , and 44. The digested DNA was hybridized using a 
A

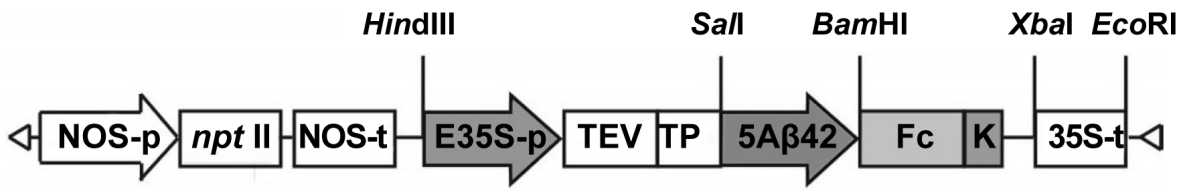

5Aß42-FcK pBINPLUS

B

\section{Expected protein structure}

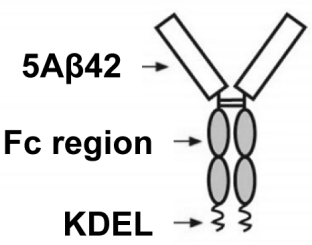

\section{Expected glycan structure}
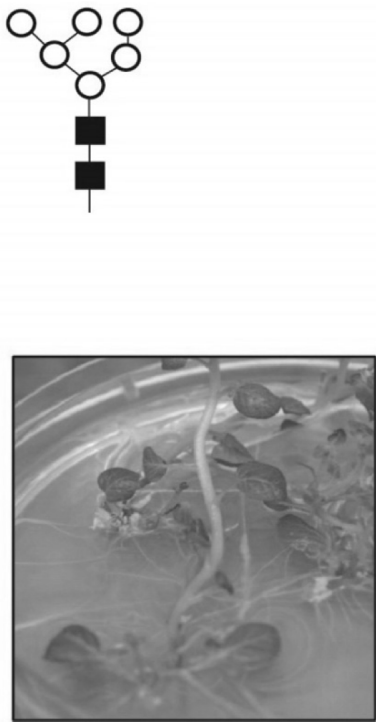

Fig. 1. Plant expression vector and schematic diagram of the assembly of the recombinant fusion protein. A. This binary vector contains the nptII gene under the control of the NOS promoter (NOS-p) for a selectable marker to confer resistance to the antibiotic kanamycin. The constructs carry the left (LB) and right borders (RB) of the transferred DNA that demarcates the sequences that are incorporated into the plant genomic DNA via Agrobacterium-mediated transformation. E35S-p, enhanced cauliflower mosaic virus 35S promoter; TEV, tobacco etch virus 5'-UTR; TP, ER transit peptide; 5Aß42; Fc; K, KDEL, ER retention signal; and 35S-t, CaMV35S terminator. B. Expected structure of $5 \mathrm{~A} \beta-\mathrm{FcK}$ and glycan structures. White square, 5Aß42; gray ellipse, Fc region; wave, KDEL. The symbols of the glycan structures are as follows: $N$-acetylglucosamine, black square; mannose, white circle. C. Putative transformed potato callus (left); putative potato regenerants (middle); transgenic in vitro potato plantlets (right).

digoxigenin-labeled Fc fragment probe, which was generated using the PCR DIG Labeling Mix (Roche Diagnostics, Mannheim, Germany) with a specific primer set for the $F c$ gene. After overnight hybridization, the membrane was detected using the DIG Detection Kit following the manufacturer's instructions (Roche Diagnostics). The DNA was blotted onto a positively charged nylon membrane (GE Healthcare, Piscataway, NJ) and incubated in a prehybridization buffer for $2 \mathrm{~h}$ at $65^{\circ} \mathrm{C}$. After membrane activation, it was hybridized using a PCRamplified and Dig-labeled specific $A \beta$ probe at $65^{\circ} \mathrm{C}$ overnight. A non-radioactive method was used for the membrane detection according to the Dig Detection kit manufacturer's protocol (Roche Applied Science, Indianapolis, IN).

\section{Northern Hybridization}

Total RNA from the leaves of transgenic and non-transgenic potato plants was isolated using the RNAgents (Total RNA isolation system, Promega, Madison, WI) according to the manufacturer's instructions. The concentration of isolated total RNA was determined by measuring the absorbance at $260 \mathrm{~nm}$. Thirty micrograms of total RNA was denatured and analyzed by northern blotting, as previously described (Youm et al., 2008). For northern blotting, the $A \beta$-specific probe was amplified by PCR and labeled using the Dig Labeling kit (Roche Applied Science, Indianapolis, IN). The denatured RNA was fractionated in a $1 \%$ agarose gel by using a $1 \times$ MOPS buffer, blotted to a positively charged 
nylon membrane (GE Healthcare, Piscataway, NJ), and then hybridized and detected using the Dig-labeled specific $A \beta$ probe at $68^{\circ} \mathrm{C}$.

\section{SDS-PAGE and Protein Blot Analysis}

Transgenic potato plants were homogenized in $200 \mu \mathrm{L}$ of extraction buffer, which contained phosphate-buffed saline (PBS, Sigma), $1 \mathrm{mM}$ EDTA, 0.1\% Triton X-100, $5 \mathrm{mM}$ 2-mercaptoethanol, and $1 \times$ proteinase inhibitor cocktail (Roche Co., Germany), and quantified by the Bradford method. The extracted total soluble protein was loaded in $12.5 \%$ SDS-PAGE and then transferred to the Immobilon-P Transfer Membrane (Millipore Corp., Bedford, MA) by using the mini-Protean II $^{\mathrm{TM}}$ system (Bio-Rad Labs, Hercules, CA) according to the manufacturer's recommendations. The transferred membrane was incubated with rabbit antihuman A $\beta$ IgG (Applied Biosystems) or goat anti-human Fc IgG and detected using a "SuperSignal" chemiluminescence substrate (Pierce, Rockford, IL). The detected signal of the membrane was visualized using an X-ray film.

\section{Results}

\section{PCR to Confirm the Presence of $5 A \beta-F c$ Fusion DNA in a Transformed Potato}

The presence of the $5 A \beta-F c$ fusion gene from transgenic and non-transgenic potato plants was confirmed by PCR analysis (Fig. 2). In PCR analysis, the $5 A \beta-F c$ transgenic gene DNA was observed in a transgenic potato plant but not in a non-transgenic potato plant (Fig. 2). KDEL, the ER retention signal sequence, was added to the $\mathrm{C}$-terminus of the Fc to retain and accumulate $A \beta-F C$ in the ER.

\section{Southern Blot Analysis of the $5 A \beta-F c$ gene in Transgenic Potato}

The presence of the DNA inserted into the potato genome was assessed by Southern blot analysis. Southern blot

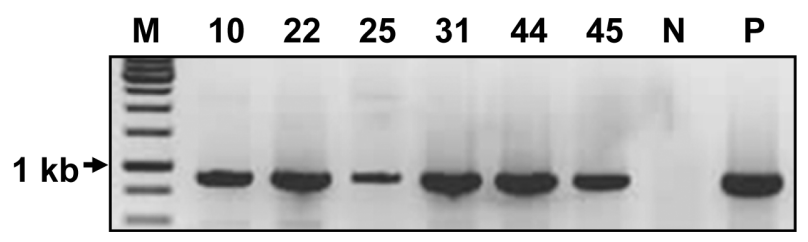

Fig. 2. Detection of the $F c$ gene in transgenic potato plants. The PCR product was separated on an agarose gel. The expected product size was to $950 \mathrm{bp}$. N, genomic DNA from non-transgenic potato. Lanes 10-45, genomic DNA from transgenic potato lines pE5AßFcK. Lane P, plasmid DNA as positive control. showed that the band for the target gene DNA (i.e., $5 A \beta-F c$ DNA) was detected in the transgenic potato plant by using a specific probe for the target gene (Fig. 3). In transgenic line 22 , a single band was observed, whereas in lines 31 and 44 , multiple bands were detected.

\section{Transcription of the $5 A \beta-F c$ Gene in a Transgenic Potato}

Transcription of $5 A \beta-F c$ fusion mRNA in the transgenic lines 22, 31, and 44 was determined by northern blot analysis (Fig. 4). The RNA was extracted from the leaf tissue of untransformed and transformed potato plants. Target gene expression was shown by using the Dig-labeled system. The expression levels of $5 A \beta-F c$ RNA were quite different in the transgenic plants. The specific probe of the target gene was bound, which clearly showed the band

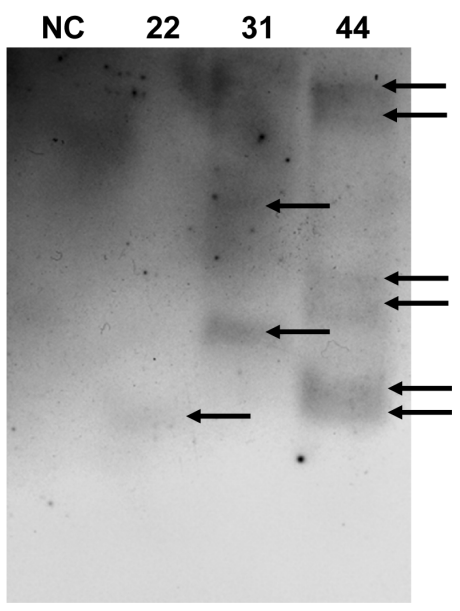

Fig. 3. Southern blot analysis of transgenic $5 A \beta-F c K$ potato lines. Genomic DNA (30 $\mu \mathrm{g})$ was isolated from transgenic and non-transgenic potatoes and digested with Sall. NC: genomic DNA from a non-transgenic potato. Numbers 22, 31 , and 44, genomic DNA from transgenic potato lines 22, 31 , and 44. Arrows indicate the detected bands in each sample.

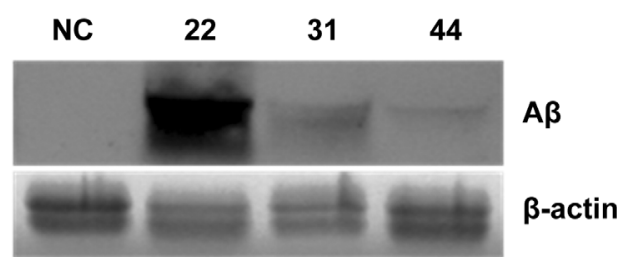

Fig. 4. Detection of $\beta$-amyloid $(A \beta)$ mRNA in the leaf of transgenic potato plants. Total RNA (30 $\mu \mathrm{g})$ from non-transgenic potato (NC) leaf and transgenic potato leaf was separated on a formaldehyde agarose gel followed by northern blot analysis and hybridization by using a Dig-labeled $\mathrm{A} \beta$ fragment. Lane $\mathrm{NC}$, non-transgenic potato. Lanes 1-3, transgenic potato lines 22 , 31, and 44, respectively. 
in the RNA of the transgenic plant. However, there was no band in the non-transgenic plant.

\section{Immunoblot Analysis to Confirm Expression of the $5 A \beta-F C$ Fusion Protein}

Expression of the $5 A \beta-F c$ fusion protein was identified in a total soluble protein (TSP) extract from the tubers of transgenic potato plants. Ten microgram, $25 \mu \mathrm{g}$, and $50 \mu \mathrm{g}$ of TSP were loaded onto a 12\% SDS-PAGE. A nontransgenic potato plant was used as the negative control. The $5 A \beta-F c$ fusion protein was detected by an anti-human $\mathrm{Fc}_{\gamma}$ fragment-specific antibody conjugated to horseradish peroxidase, and the expected molecular mass was observed on $50 \mathrm{kDa}$. The $5 \mathrm{~A} \beta-\mathrm{Fc}$ fusion protein was detected with the strongest signal in $50 \mu \mathrm{g}$ of TSP. In contrast, the band was weakly detected in $10 \mu \mathrm{g}$ of TSP. No band was detected in the non-transgenic potato plant (Fig. 5).

\section{Discussion}

Our data showed that the $5 A \beta$ protein could be fused to the $\mathrm{Fc}$ of human $\mathrm{IgG}_{1}$ and expressed in the potato plant. In this study, transgenic potato plant lines expressing $5 \mathrm{~A} \beta-\mathrm{FcK}$ were established via $5 \mathrm{~A} \beta$ expression. Both PCR and northern blot analyses showed that randomly tested transgenic plants, each containing the $5 \mathrm{~A} \beta-\mathrm{FcK}$ transgene, expressed the transgene transcript. The immunoblot analysis showed $5 \mathrm{~A} \beta-\mathrm{FcK}$ protein expression in transgenic plants. Among the transgenic lines tested by northern blot analysis, $5 \mathrm{~A} \beta$-FcK transgenic plant line 22 had the strongest transcription level. This high expression of $5 \mathrm{~A} \beta-\mathrm{FcK}$ can be explained

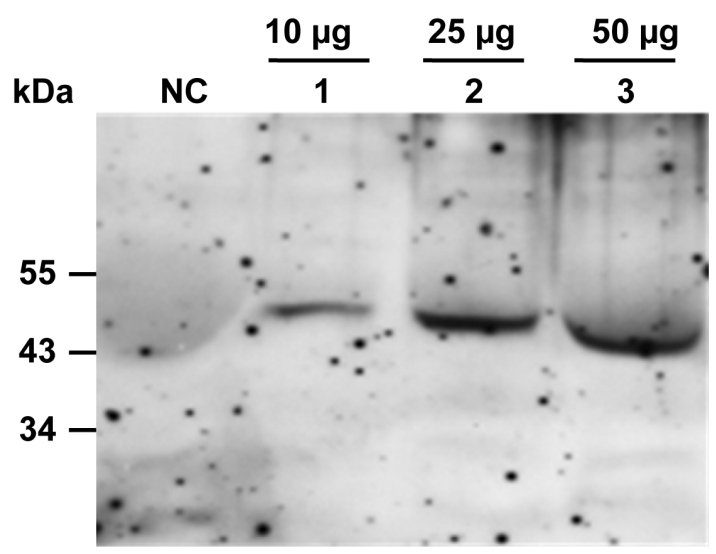

Fig. 5. Immunoblot with horseradish peroxidase-conjugated anti-Fc-specific human IgG to confirm the expression of monoclonal antibodies in a transgenic potato plant (line 22). The expected protein size of the $5 \mathrm{~A} \beta 42-\mathrm{FcK}$ fusion protein is to $50 \mathrm{kDa}$. by the single copy number of the $5 A \beta-F c K$ gene in line 22. In contrast, lines 31 and 44 had multiple copy numbers of the $5 A \beta-F c K$ gene. These lines showed low transcription signals. Western blot analysis was conducted to confirm the expressions of the $5 \mathrm{~A} \beta-\mathrm{FcK}$ fusion protein, indicating that the $5 \mathrm{~A} \beta-\mathrm{FcK}$ fusion proteins were stable in line 22 . Fusion of the $\mathrm{Fc}$ fragment to $5 \mathrm{~A} \beta$ has the obvious advantage of an easy, one-step purification procedure by using the protein a method.

As a source of the recombinant $5 \mathrm{~A} \beta-\mathrm{Fc}$ antigen, soluble Fc fusion proteins have become valuable reagents for immunotherapy and laboratory investigations. Furthermore, the immunoadhesion antibody-like protein design resulted in soluble protein accumulation in plant tissues. It is expected that $5 \mathrm{~A} \beta-\mathrm{FcK}$ would have high-mannose glycan structures. In previous studies, Fc fusion with KDEL had high-mannose glycan structures (Lu et al., 2012). The KDEL ER retention signal efficiently retained the glycoproteins, thus, yielding proteins with high mannose (Lee et al., 2013). The antigenantibody complex can enhance the efficiency and effectiveness of vaccination by targeting the vaccine to APCs. No study has shown that the common Fc-receptors on mouse APC interact efficiently with human IgG Fc. In addition, the oligomannose-type N-glycan structure would be expected to cause an enhanced immune response through the mannose receptor (MR) on macrophages and dendritic cells, which then recognizes the oligomannose of GA733-FcK (Ahlén et al., 2012).

According to a previous study (Lee et al., 2013), the ER-type glycans on glycoproteins, which are also known as oligomannose glycan-types, can further make the glycoprotein immunogenic, thus, producing IgG against the oligomannose glycosylated protein itself. In fact, some studies have shown that the Fc fusion protein can efficiently prevent or treat disease (Hu, 2008; Tobinick and Gross, 2008). The capability of the Fc region to induce an effective immune response has been suggested because dendritic cell-based antitumor immunotherapy is an efficient method for cancer therapy (Armstrong et al., 2002; Liu et al., 1998; Mosolits et al., 2004; Syrengelas and Levy, 1999). In addition, posttranslational modification occurs in the ER. The KDEL can act as an autonomous retrieval signal and is introduced at the C-terminus for optimum targeting, with accumulation of interesting genes in transgenic plant glycosylation (Agarwal et al., 2008; Petruccelli et al., 2006). N-glycans of mammalian glycoproteins produced in transgenic plants differ from their natural forms (Lerouge, 1998). If the transgenic protein is directed toward and retained in the ER, then $80 \%$ of the total $N$-glycans attached to ER-resident proteins in the 
transgenic plant would be high-mannose-type $\mathrm{N}$-glycans (Helenius and Aevi, 2001; Triguero, 2005). The use of the ER-retention signal has been proposed to restrict glycosylation of plant-derived antibodies or the vaccine to only highmannose-type N-glycans (Triguero, 2005). However, in this study, the effect of Fc and KDEL on the expression levels and glycosylation patterns could not be investigated since we did not include $5 A \beta$ without $F c$ or $5 A \beta-F c$. Future studies need to be conducted by testing these recombinant proteins with $5 \mathrm{~A} \beta-\mathrm{FcK}$.

In this study, the data clearly showed the expression of a $5 \mathrm{~A} \beta-\mathrm{FcK}$ fusion vaccine candidate in potato plant expression systems. Fusion of the Fc fragment of human IgG to the C-terminus of $5 \mathrm{~A} \beta$ and the ER retention KDEL in $5 \mathrm{~A} \beta-\mathrm{FcK}$ is an ideal strategy to easily purify recombinant $5 \mathrm{~A} \beta$ vaccine candidate proteins. Moreover, it enhances the accumulation of the recombinant proteins, which contain oligomannose for comparable immunogenicity of the nonKDEL-tagged mammalian-derived proteins, in plant expression systems. Here, we did not study the addition of the KDEL ER retention signal to the $5 \mathrm{~A} \beta-\mathrm{Fc}$ fusion protein to enhance the expression of the fusion protein in the potato plant. In the future, we will investigate whether the ER retention signal allows control over the subcellular localization of the $5 \mathrm{~A} \beta-\mathrm{Fc}$ fusion protein and whether different glycostructural patterns of $5 \mathrm{~A} \beta$-FcK biological activities are generated in the potato plant.

\section{Literature Cited}

Agarwal, S., R. Singh, I. Sanyal, and D.V. Amla. 2008. Expression of modified gene encoding functional human alpha-1-antitrypsin protein in transgenic tomato plants. Transgenic Res. 7:881-896.

Ahlén, G., L. Strindelius, T. Johansson, A. Nilsson, N. Chatzissavidou, M. Sjöblom, U. Rova, and J. Holgersson. 2012. Mannosylated mucin-type immunoglobulin fusion proteins enhance antigenspecific antibody and $\mathrm{T}$ lymphocyte responses. PLoS One. 7(10):e46959. doi: 10.1371/journal.pone.0046959.

Armstrong, A.C., S. Dermime, C.G. Allinson, T. Bhattacharyya, K. Mulryan, K.R. Gonzalez, P.L. Stern, and R.E. Hawkins. 2002. Immunization with a recombinant adenovirus encoding a lymphoma idiotype: Induction of tumor-protective immunity and identification of an idiotype-specific T cell epitope. J. Immunol. 168:3983-3991.

Brodzik, R., M. Glogowska, K. Bandurska, M. Okulicz, D. Deka, K. Ko, J. van der Linden, J.H. Leusen, N. Pogrebnyak, M. Golovkin, Z. Steplewski, and H. Koprowski. 2006. Plant-derived anti-Lewis Y mAb exhibits biological activities for efficient immunotherapy against human cancer cells. Proc. Natl. Acad. Sci. USA. 103:8804-8809.
Buyel, J.F., J.A. Bautista, R. Fischer, and V.M. Yusibov. 2012. Extraction, purification and characterization of the plant-produced HPV16 subunit vaccine candidate E7 GGG. J. Chromatogr B Analyt Technol. Biomed Life Sci. 880:19-26.

Chen, Q. and H. Lai. 2013. Plant-derived virus-like particles as vaccines. Hum Vaccin Immunother. 9:26-49.

Cuadros, C., F.J. Lopez-Hernandez, A.L. Dominguez, M. McClelland, and J. Lustgarten. 2004. Flagellin fusion proteins as adjuvant or vaccines induce specific immune responses. Infect. Immun. 72:2810-2816.

Cueno, M.E., Y. Hibi Y., K. Karamatsu, Y. Yasutomi, K. Imai, A.C. Laurena, and T. Okamoto. 2010. Preferential expression and immunogenicity of HIV-1 Tat fusion protein expressed in tomato plant. Transgenic Res. 19:889-895.

Doyle, J.J. and J.L. Doyle. 1990. A rapid total DNA preparation procedure for fresh plant tissue. Vivo 12:13-15.

Emini, E.A., R.W. Ellis, W.J. Miller, W.J. McAleer, E.M. Scolnick, and R.J. Gerety. 1986. Production and immunological analysis of recombinant hepatitis B vaccine. J. Infect. 13:3-9.

Gradinaru, V., K.R. Thompson, K. Deisseroth. 2008. eNpHR: A natronomonas halorhodopsin enhanced for optogenetic applications. Brain Cell Biol. 36:129-139.

Helenius, A. and M. Aebi. 2001. Intracellular functions of $N$-linked glycans. Science 291:2364-2369.

Hu, D., C. Bao, S. Chen, J. Gu, Z. Li, L. Sun, X. Han, and L. Ni. 2008. A comparison study of a recombinant tumor necrosis factor receptor:Fc fusion protein (rhTNFR:Fc) and methotrexate in treatment of patients with active rheumatoid arthritis in China. Rheumatol Int. 29:297-303.

Kanai, Y., T.N. Athmaram, M. Stewart, and P. Roy. 2013. Multiple large foreign protein expression by a single recombinant baculovirus: A system for production of multivalent vaccines. Protein Expr Purif. 91:77-84.

Ko, K., Y. Tekoah, P.M. Rudd, D.J. Harvey, R.A. Dwek, S. Spitsin, C.A. Hanlon, C. Rupprecht, B. Dietzschold, M. Golovkin, and H. Koprowski. 2003. Function and glycosylation of plantderived antiviral monoclonal antibody. Proc. Natl. Acad. Sci. USA. 100:8013-8018.

Kreutz, M., B. Giquel, Q. Hu, R. Abuknesha, S. Uematsu, S. Akira, F.O. Nestle, and S.S. Diebold. 2012. Antibody-antigenadjuvant conjugates enable co-delivery of antigen and adjuvant to dendritic cells in cis but only have partial targeting specificity. PLoS One. 7(7):e40208. doi: 10.1371/journal.pone.0040208.

Langridge, W., B. Dénes, and I. Fodor. 2010. Cholera toxin B subunit modulation of mucosal vaccines for infectious and autoimmune diseases. Curr. Opin. Investig. Drugs 11:919-28.

Lee, J.H., D.Y. Park, K.J. Lee, Y.K. Kim, Y.K. So, J.S. Ryu, S.H. Oh, Y.S. Han, K. Ko, Y.K. Choo, S.J. Park, R. Brodzik, K.K. Lee, D.B. Oh, K.A. Hwang, H. Koprowski, Y.S. Lee, and K. Ko. 2013. Intracellular reprogramming of expression glycosylation, and function of a plant derived antiviral therapeutic monoclonal antibody. PLoS One. 8:(e68772)1-9. 
Lerouge, P., M. Cabanes-Macheteau, C. Rayon, A.C. Fischette-Laine, V. Gomord, and L. Faye. 1998. N-glycoprotein biosynthesis in plant: Recent developments and future trends. Plant Mol Biol. 38:31-48.

Liu, S.J., Y.P. Sher, C.C. Ting, K.W. Liao, C.P. Yu, and M.H. Tao. 1998. Treatment of B-cell lymphoma with chimeric IgG and single-chain Fv antibody-interleukin-2 fusion proteins. Blood 92:2103-2112.

Lo, K.M., Y. Sudo, J. Chen, Y. Li, Y. Lan, S.M. Kong, L. Chen, Q. An, and S.D. Gillies. 1998. High level expression and secretion of Fc-X fusion proteins in mammalian cells. Protein Eng. 11:495-500.

Lu, Z., K.J. Lee, Y. Shao, J.H. Lee, Y. So, Y.K. Choo, D.B. Oh, K.A. Hwang, S.H. O, Y.S. Han, and K. Ko. 2012. Expression of GA733-Fc fusion protein as a vaccine candidate for colorectal cancer in transgenic plants. J. Biomed. Biotechnol. 364240. doi: 10.1155/2012/364240.

Ma, Y., Y.Z. Yu, Y.F. Zhu, Q. Xu, and Z.W. Sun. 2013. In vitro and in vivo activities of recombinant anthrax protective antigen co-expressed with thioredoxin in Escherichia coli. Hum Vaccin Immunother. 9:2371-2377.

Ma, J.K., P.M. Drake, and P. Christou. 2003. The production of recombinant pharmaceutical proteins in plants. Nat. Rev. Genet. 4:794-805

Moretto, N., A. Bolchi, C. Rivetti, B.P. Imbimbo, G. Villetti, V. Pietrini, L. Polonelli, S.D. Signore, K.M. Smith, R.J. Ferrante, and S. Ottonello. 2007. Conformation-sensitive antibodies against Alzheimer amyloid- $\beta$ by immunization with a thioredoxinconstrained B-cell epitope peptide. J. Biol. Chem. 282:1143611445.

Morgan, D., D.M. Diamond, P.E. Gottschall, K.E. Ugen, C. Dickey, J. Hardy, K. Duff, P. Jantzen, G. DiCarlo, D. Wilcock, K. Connor, J. Hatcher, C. Hope, M. Gordon, and G.W. Arendash. 2000. A beta peptide vaccination prevents memory loss in an animal model of Alzheimer's disease. Nature 408:982-985.

Mosolits, S., F. Campbell, S.V. Litvinov, J. Fagerberg, J.S. Crowe, H. Mellstedt, and J.H. Ellis. 2004. Targeting human Ep-CAM in transgenic mice by anti-idiotype and antigen based vaccines. Int. J. Cancer. 112:669-677.

Murashige, T. and F. Skoog. 1962. A revised medium for rapid growth and bio assays with tobacco tissue cultures. 15:473-497.

Nicoll, J.A., D. Wilkinson, C. Holmes, P. Steart, H. Markham, and R.O. Weller. 2003. Neuropathology of human Alzheimer disease after immunization with amyloid-beta peptide: A case report. Nat. Med. 9:448-452.

Orgogozo, J.M., S. Gilman, J.F. Dartigues, B. Laurent, M. Puel, L.C. Kirby, P. Jouanny, B. Dubois, L. Eisner, S. Flitman, B.F. Michel, M. Boada, A. Frank, and C. Hock. 2003. Subacute meningoencephalitis in a subset of patients with $\mathrm{AD}$ after $\mathrm{A} \beta 42$ immunization. Neurology 61:46-54.

Petruccelli, S, M.S. Otegui, F. Lareu, O. Tran Dinh, A.C. Fitchette, A. Circosta, M. Rumbo, M. Bardor, R. Carcamo, V. Gomord, and R.N. Beachy. 2006. A KDEL-tagged monoclonal antibody is efficiently retained in the endoplasmic reticulum in leaves, but is both partially secreted and sorted to protein storage vacuoles in seeds. Plant Biotechnol. J. 4:511-527.

Racchi, M, D. Uberti, S. Govoni, M. Memo, C. Lanni, S. Vasto, G. Candore, C. Caruso, L. Romeo, and G. Scapagnini. 2008. Alzheimer's disease: New diagnostic and therapeutic tools. Immun. Ageing. 13:5-7.

Richter, L.J., Y. Thanavala, C.J. Arntzen, and H.S. Mason. 2000. Production of hepatitis B surface antigen in transgenic plants for oral immunization. Nat. Biotechnol. 18:1167-1171.

Schenk, D., R. Barbour, W. Dunn, G. Gordon, H. Grajeda, T. Guido, K. Hu, J. Huang, K. Johnson-Wood, K. Khan, D. Kholodenko, M. Lee, Z. Liao, I. Lieberburg, R. Motter, L. Mutter, F. Soriano, G. Shopp, N. Vasquez, C. Vandevert, S. Walker, M. Wogulis, T. Yednock, D. Games, and P. Seubert. 1999. Immunization with amyloid-beta attenuates Alzheimerdisease-like pathology in the PDAPP mouse. Nature 400:173-177.

Syrengelas, A.D. and R. Levy. 1999. DNA vaccination against the idiotype of a murine B cell lymphoma: Mechanism of tumor protection. J. Immunol. 162:4790-4795.

Tacket, C.O., H.S. Mason, G. Losonsky, J.D. Clements, M.M. Levine, and C.J. Arntzen. 1998. Immunogenicity in humans of a recombinant bacterial antigen delivered in a transgenic potato. Nat. Med. 4:607-609.

Tobinick, E.L. and H. Gross. 2008. Rapid improvement in verbal fluency and aphasia following perispinal etanercept in Alzheimer's disease. BMC Neurol. 8:27. doi: 10.1186/1471-2377-8-27.

Triguero, A., G. Cabrera, J.A. Cremata, C.T. Yuen, J. Wheeler, and N.I. Ramirez. 2005. Plant-derived mouse IgG monoclonal antibody fused to KDEL endoplasmic reticulum-retention signal is $\mathrm{N}$-glycosylated homogeneously throughout the plant with mostly high-mannose-type $N$-glycans. Plant Biotechnol J. 3: 449-457.

Urakami, E., I. Yamaguchi, T. Asami, U. Conrad, and Y. Suzuki. 2008. Immunomodulation of gibberellin biosynthesis using an anti-precursor gibberellin antibody confers gibberellin-deficient phenotypes. Planta 228:863-873.

Wang, M., S. Jiang, X. Liu, and Y. Wang. 2013. Expression, purification, and immunogenic characterization of Epstein-Barr virus recombinant EBNA1 protein in Pichia pastoris. Appl. Microbiol. Biotechnol. 97:6251-6262.

Weiner, H.L. and D. Frenkel. 2006. Immunology and immunotherapy of Alzheimer's disease. Nat. Rev. Immunol. 6:404-416.

Youm, J.W., H. Kim, J.H. Han, C.H. Jang, H.J. Ha, I. Mook-Jung, J.H. Jeon, C.Y. Choi, Y.H. Kim, H.S. Kim, and H. Joung. 2005. Transgenic potato expressing $A \beta$ reduce $A \beta$ burden in Alzheimer's disease mouse model. FEBS Letters 579:6737-6744.

Youm, J.W., J.H. Jeon, H. Kim, Y.H. Kim, K. Ko, H. Joung, and H. Kim. 2008. Transgenic tomatoes expressing human beta-amyloid for use as a vaccine against Alzheimer's disease. Biotechnol Lett. 30:1839-1845. 